\title{
The Austrian Civil War of 1934: Harvard and Vienna Conferences
}

\section{Anson Rabinbach}

The Institute for Advanced Study, Princeton \&

The Cooper Union

The Austrian civil war of February 1934, which marked the first mass European working class resistance to fascism, and drove the strongest social democratic labor movement into illegality and exile, was the subject of two important conferences in Cambridge, Mass. and Vienna. At a colloquium at the Harvard Center for European Studies, co-sponsored by the Austrian Institute in New York, scholars from Europe and the United States met for three days (February 10th to 12th) to discuss new research and new approaches to "Austrian Social Democracy 1918-1934: A Socialist Experiment and its Collapse." The discussions at the Harvard colloquium were lively and well informed, attesting to a decade of new research on many aspects of the First Republic. Most participants shared the view that the events of February 1934 had to be placed within a broad framework emphasizing the limits on the First Republic: the social and psychological effects of World War I; the widely shared belief that the First Republic was "incapable of survival"; the political tensions in the Republic, characterized by separate "camps", each with a private army and a strong ideological orientation; and a general lack of loyalty to the "Austrian nation." Far more diverse was the spectrum of opinions on the degree of socialist commitment to both the Republic and democracy, and on the role of Hitler and Mussolini in sealing the fate of the Republic.

Melanie Sully (United Kingdom) reminded the participants of the profound ambivalence evident in the programmatic statements of the socialists, especially in the famous Linz program of 1926, which defended both democracy and revolutionary dictatorship. Klemens von Klemperer (Northhampton, Mass.) stressed the structural weaknesses of the Republic and distributed "responsibility" more widely. He drew attention to the primacy of "Grossraumdenken", the militarization of politics, and deepening ideological tensions - as well as the authoritarianism inherited from the Habsburg epoch. Gerhard Botz (Salzburg) discussed the widespread political violence in the Republic, pointing out that there were similarities between the fascist Heimwehr, the Socialist Schutsbund, and non-Austrian, Communist military policies elsewhere. Anton Pelinka (Innsbruck) focused on the "camp mentality" of the first Republic pointing out that it was neither the constitution nor the personalities of the political elites that could be held responsible, since both remained essentially the same in the era of coalition politics after 1945. For him the explanation for the camp mentality lay in the fundamental instability of the first Republic as 
a political system, its lack of self-confidence, nostalgia for Anschluss, lack of democratic traditions and the destablizing role of the Church, which was officially soft on fascism, neutral on democracy and opposed to the socialists. In his view the 12 th of February was a symbol of anti-democratic tendencies in Austria. As opposed to this democratization of blame, Karl R. Stadler ( Linz) warned that the working-class movement could not be held responsible for undermining the Republic or the constitution, to which it remained loyal throughout. It was a myth, he concluded, to believe that the socialists were Jacobins masquerading as Girondists.

There was also a good deal of debate about both the accomplishments and failures of Austromarxist theory and the unique cultural socialism of Red Vienna. Andrew Arato (New York) stressed the significance of Austromarxism as a political theory which tried to develop the idea of a socialist "civil society" encompassing economic, social and political democracy. In his fascinating reminiscences about the remarkable circle of intellectuals that made up the "Austromarxists," Hans Zeisel (Chigaco), co-author of the famous Die Arbeitslosen von Marienthal (1933), a pioneering social-psychological study of unemployment, recalled that they had originally planned a study of leisure time working class activities, but that Otto Bauer, the socialist leader, insisted that in the atmosphere of economic crisis such a study would be a luxury, while a study of the effects of unemployment would have great value. For Zeisel the combination of empirical social science and a commitment to social justice was the admirable core of Austromarxism.

Though some doubted that Austromarxism could be seen only in such positive terms, especially since the split between social science and social ethics seemed to lead to political passivity and (in the case of Paul Lazarsfeld) market research, most agreed that the novum of Austrian Social Democracy was its cultural edifice in Red Vienna. Peter Marcuse (New York) pointed out that the Socialist's experiment "to solve the housing question under capitalism" was radical because of its redistributive economic structure, but it was less successful than had previously been thought. Josef Weidenholzer ( $\operatorname{Linz}$ ) stressed the tension in the educational activities of the socialists between producing a mechanism for quiescent social integration of the rank and file and the means of maintaining the militancy of party officials. Anson Rabinbach (New York) also discussed the pedagogical efforts of the party, pointing out that Red Vienna was more successful as a symbol, a legitimation for the party's failures in politics, for which it was a compensation.

Helmut Gruber (New York) found the emphasis on the party's cultural efforts one-sided, since those efforts tended to exclude a great portion of the working class, were often puritanical, male dominated and sometimes even the source of resentment among working women who found communal facilities such as laundries in the municipal housing complexes burdensome and unresponsive to their real needs. Though some stalwarts still defended the collective laundry as a sign of progress and an end to a kitchen dominated by drying linens, diapers etc., Gruber's appeal for more anthropological studies of the working class milieu in the interwar period was generally applauded. Some participants, especially Peter Loewenberg (Los Angeles) and William McGrath (Rochester) were even more sceptical of the party's cultural achievements and argued that these efforts fit into the characteristically 
Viennese artistic "politics of metaphor" which created illusions about the power of the socialists in Vienna.

The conference concluded on a broader, comparative note, in which the weakness of all interwar socialist parties, characterized by the cumulative weight of the breakup of the European monarchies, the terrible toll of the war, and the endemic fear of coalitions on their political fate were underlined.

The Vienna symposium at the Renner-Institut, entitled "The 12th of February 1934: Causes, Facts and Consequences," held from 13th to 15th February, also included strong international participation from the U.S., England, and Germany, as well as from Hungary, Czechoslovakia, and the German Democratic Republic. Although many of the same themes were raised in Vienna as at the Harvard colloquium, there was greater emphasis placed on the Austrian international situation in 1934, and on the later period of corporatism, illegality, and the emigration between 1934 and 1938. Relations between the Austrian socialists and the fraternal parties in Budapest, Moravia and the impact of the events of February 6, 1934 in Paris received careful attention.

The most controversial point of the conference in Vienna was Norbert Leser's (Vienna) assertion that the "missed opportunity" of the Austrian socialists was their failure to form a coalition government with the Christian Social party in 1931, which he attributed to Social Democratic rigidity and ideological intransigence. This statement naturally created something of a minor sensation. In one of the more dramatic moments of the conference, Herbert Steiner (Vienna), Rudolf Neck (Vienna) and Anton Staudinger (Vienna) tried to demonstrate that Leser's account neglected the historical realities of the 1930s, as revealed by recent archival discoveries. Staudinger pointed out that the minutes of the Christian social club meetings made clear that they too were unwilling to participate in a government with the Socialists.

The Vienna symposium also emphasized the importance of the party's military strategy, which was discussed by Barry McLoughlin (Vienna) and Wolfgang Maderthaner (Vienna). Along with Gerhard Botz (Salzburg) who discussed the social characteristics of Austrian fascism and Helmut Konrad (Graz), they emphasized the importance of new regional and sociological approaches to the study of interwar Austria. Konrad especially pointed out that substantial regional projects on the working class had either been accomplished (including his own) or were underway, but that these had not yet been synthesized in a coherent manner. Nontheless, it is apparant that Austrian social history is no longer lagging as far behind France, Germany, and the anglo-saxon countries, as had been the case.

Though both conferences provided a good deal of stimulating new material, the format of the Vienna symposium was extremely formalistic, with long papers and sometimes even longer statements from the floor, leaving little room for the exciting and often sharp debate that characterized the Harvard event. It should also be noted that in Vienna, the appointments of two extremely capable young historians to archival directorships, Dr. Wolfgang Neugebauer to the Dokumentationsarchiv des österreichischen Widerstandes and Dr. Wolfgang Maderthaner to the Verein für Geschichte der Arbeiterbewegung, will be of interest to scholars interested in pursuing themes raised at both conferences. 